\title{
Methods to Measure and Track Population Perception and Support within a Manual Wargame Jeremy Smith, Stephen Barker
}

Jeremy Smith,

Cranfield Defence and Security, Cranfield University, UK Defence Academy, Shrivenham, Swindon, Wiltshire, SN6 8LA, UK, j.d.smith@cranfield.ac.uk

Stephen Barker,

Cranfield Defence and Security, Cranfield University, UK Defence Academy, Shrivenham, Swindon, Wiltshire, SN6 8LA, UK, S.G.Barker@cranfield.ac.uk

Highlights -

1. Population perception and response in a military campaign can be modelled using Maslow's Hierarchy of Needs

2. Levels within the Maslow Hierarchy are amenable to being ranked numerically

3. Military Effects can be related in a simple quantification to an impact on a population

This research did not receive any specific grant from funding agencies in the public, commercial, or not-for-profit sectors. The Authors declare that there is no conflict of interest.

Abstract-The outcome of military campaigns depend to a large extent on the support of local and other wider population groups, so it is important to understand their perceptions. Here we briefly describe the approach used to represent support for organisations and factions in a professional wargame designed to represent military campaigns. This specific approach was developed originally using a simple marker track system which used a basic quantified set of relationships between military campaign effects and changes to the track levels. This marker track system was developed for military campaign wargames in the UK as a means to portray support or dissent in population groups relevant to the operations but there was originally no mechanism to drive changes other than by expert judgement. Our improved approach continues the use of marker tracks but attempts to develop a more defensible method based on Maslow's hierarchy of needs for linking events to changes and levels on the tracks. We conducted experiments to quantify the relative importance of each element in Maslow's hierarchy. We then continued by conducting a further experiment to identify the impact of a set of effects seen in a wargame against the Maslow elements. This has led to a set of quantified scores that may be used to drive the modifications to the marker tracks when wargame events occur. These scores are based on our initial experiments and may be updated for a specific application, perhaps for a specific setting or location in the world. The revised or enhanced approach aims to produce a transparent solution that can be understood by a military or security analyst, thus facilitating refinement, updating and change.

Keywords-Wargame, Population perception, Population opinion, Maslow, Military effects 


\section{INTRODUCTION}

1.1 In military campaigns and other operations, the overall outcome is strongly influenced by the impact of kinetic and nonkinetic factors on the human terrain, which includes population locations and descriptions (Kipp, [1]). The perception of the campaign and the level of support or opposition among different population groups for the various factions participating in the campaign have an important impact on long-term success of the campaign, whether by military or other means. These population groups can include local populations in regions or towns in the theatre of operation, wider national populations, home-nation groups, religious communities, political parties, large organisations such as the media, and governments or combinations of these. In a specific setting there may be a large number of such population groups. The factions may include local military forces, local police, external military forces, militias and insurgents, and non-state actors.

1.2 Military campaigns have been represented in defence and security analysis using a variety of wargaming methods and tools (Rubel [2], Dunnigan[3], Taylor [4]), One example developed in part by the authors is the Rapid Campaign Analysis Toolset (RCAT) (Smith [5]). This is a manual wargame system for the evaluation of military campaigns which was developed from 2012 by Cranfield University for the UK's Defence Science and Technology Laboratory (DSTL). During the development of RCAT the designers ran a series of workshops to examine historical campaigns and the factors that influenced them, this revealed, in part, that the perception of a campaign by population groups and factions is an important feature that must be included. This conclusion was drawn within the design workshop and is supported by the historical literature.

1.3 Accordingly, it was necessary to include in the wargame some elements that represented the perception of campaigns by populations and then attempted to derive an impact on campaign success. However, quantitative analysis of these factors was challenging due to the absence of detailed modelling data or other forms of representation. For example, Appleget [6] attempted to frame the human terrain situation and to establish a modelling framework without completing the development of a comprehensive or validated tool. Sandel[7] and Silverman [8] suggested that the problem was complex and lacked a simple solution. The conclusion was that there were no readily accessible methods which were appropriate for use in RCAT and therefore, due to this lack of any existing approach a new one was developed specifically for the RCAT wargame. The approach designed originally represented perceptions of the population groups using marker tracks (Smith, [5]) showing the level of support for the factions (typically coalition forces, local host nation forces, enemy forces, and insurgents/non-state actors) by their level on the track (Fig. 1).
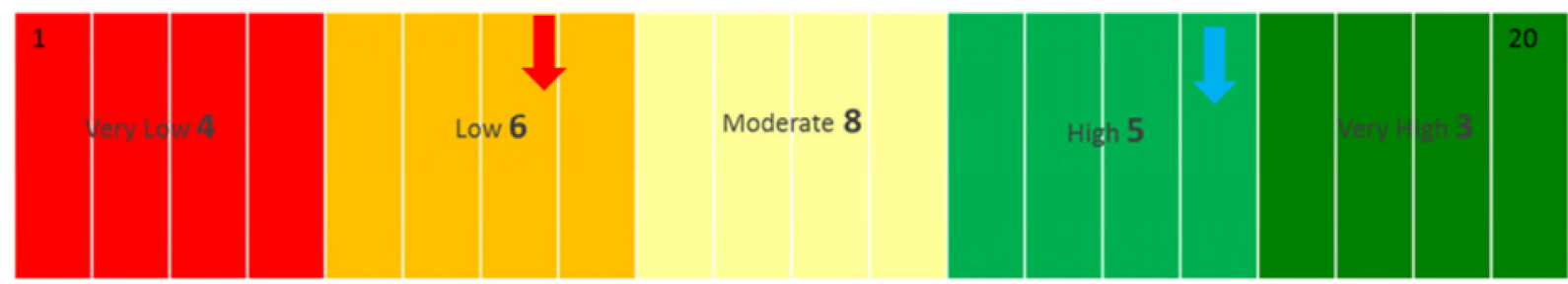

Fig. 1. Example of the use of marker tracks to gauge support in a theoretical military campaign). The scale runs from 1 (minimum support) to 20 (maximum support). The blue marker signifies that the coalition forces (Blue force) have a high degree of local support, whereas the red marker shows enemy (Red) forces have limited local support.

1.4 RCAT has an established history of use. It has been used for a large number of campaign studies carried out by the UK Ministry of Defence (MoD) and other agencies. This includes campaign analysis for future force evaluation (for MoD/DSTL) and for the training of Headquarters . When RCAT is used to analyse a campaign, the required marker tracks and the associated population groups are generally identified during the scenario-planning phase and then the starting levels of support/perception are agreed before the game begins. There have been no other similar rapid analysis wargames which have marker track mechanisms in use and this is one contributing factor driving its choice in many studies for the UK MoD.

1.5 During RCAT wargame exercises, events occur that can drive changes in the tracks. These events are within the wargame system and examples are operational successes or failures, media campaigns, atrocities, collateral damage or similar. When these occur, the impact on the tracks is often implemented by small groups of experts (typically 2 or 3 ) from the study team or audience. A simple algorithm was developed for the initial versions of RCAT which proposes or suggests changes. For example, an event resulting in collateral damage in an area will reduce support in that area (or the population in that area), for the force responsible, by one step or segment on the track. However, at the end of a turn, all such changes are wrapped up in a consolidation and review activity to determine a sensible outcome. This is known as a consequence management judgement phase, which comprises a discussion with a subgroup of experts who weigh up the changes and the activities in each turn and 
produce a verdict on the final combined changes. Thus the effects on the marker tracks are completely judgement-based and necessarily limited by the expertise present.

1.5 In this type of wargame, many of the outcomes (not only the soft factors) are determined by proposing results which are then discussed and accepted (or sometimes moderated) by the participants. This approach works well because the expertise of the players can be utilised to gather 'buy in' on the outcomes. Note that the reverse is sometimes observed in computer-based algorithmic systems, where results are simply provided and participants are unsure and sometimes disagree. This can lead potentially to disengagement and demotivation on the part of the participants.

1.6 The marker tracks are designed to be easy to interpret due to their simplicity and transparency. This is rapidly understood by the players in each exercise. These tracks have been noted by several participants in an exercise as very useful and in essence are seen to be representing a 'human terrain dashboard'.

1.7 Noting the utility of the marker track system but the limitations caused by the judgement based derivation of the changes on the tracks, it was identified that a more sophisticated method would be useful but one which still allows transparency and clarity to expose why a result has been generated and so that the participants can understand and can comment upon. This improved system would be more robust and defensible for other wargaming applications.

1.8 This article explains the development of such a more sophisticated method for quantifying the levels of perception or support for participants in a given situation. The approach uses the marker tracks but implements a more complex and quantifiable method to determine the changes in the levels on each track. The article is based upon a set of experimental data which has some utility in its initial form, but, as will be seen, the data used may require updating or at least reviewing to determine its applicability to other operational areas

\section{BACKGROUND AND LITERATURE REVIEW}

2.1 In order to improve the quantification approach, the work began with a literature review covering methods that represent human populations and their motivations, thus identifying a preferred option for application to this problem. We have found that motivation can be defined as "enthusiasm for doing something" (Cambridge online dictionary [9]), "the need or reason for doing something" (Cambridge online dictionary [9]), and the forces within an individual which push them to satisfy their basic needs (Yorks, [10]). Dessler [11] suggested that motivation stems from a tension resulting when one or more basic needs are not met.

2.2 Several theories and methods for the analysis of human motivation were examined, including Maslow's hierarchy of needs [12], Herzberg's theory [13], Theories X and Y [14, 15], and McClelland's Needs Theory [16, 17, 18, 19]. The following short section explores these briefly in order to underpin the choice of method and to set the context for the implementation.

2.3 Maslow [12] was the first to propose a hierarchy of human needs that must be fulfilled to drive motivation and wellbeing. Maslow's hierarchy of needs has five principal levels: actualisation, esteem, belonging/love, safety, and physiological. The original paper included these aspects and then discussed subordinate elements within each, but it did not produce a hierarchy of the sub-elements. These can be identified from the original text based on the reader's interpretation. In the current study, most of the levels were considered too broad to allow the effects of military action to be determined. Therefore, each was decomposed into a set of subordinate elements based on Stein [21] but modified slightly to reduce the complexity for the initial experiment. It is noteworthy that there are a number of areas where these subcategories appear to overlap or double count or they are less clear as their relevance in this application. However they were not modified for this application. It may be that use of the higher level categories would be a simpler method for future applications.

2.4 Actualisation was the only element that was not subdivided. Esteem was divided into self-esteem and external esteem, each in turn divided further as follows:

- Self-esteem: (1) achievement, competence; (2) confidence interpersonal; (3) self-acceptance, self-trust; (4) usefulness, selfworth.

- External esteem: (1) reputation, prestige; (2) status, admiration; (3) recognition, importance; (4) autonomy, respect.

Belonging/love was likewise divided into the need to love and belonging, each in turn divided further as follows:

- Need to love: (1) to be kind, express affection; (2) to help, encourage, cooperate; (3) to be responsible, share; (4) to give love, be intimate; (5) to empathise, be a friend.

- Belonging: (1) to be loved, receive affection; (2) to belong, be accepted; (3) to have a place in a group; (4) to have friends and family; (5) to be understood.

Safety was divided into interpersonal and material safety, each subdivided as follows:

- Interpersonal safety: (1) predictable situation, the familiar; (2) order, stability; (3) consistency of relationships; (4) justice, fairness; (5) freedom from interpersonal danger. 
- Material safety: (1) personal safety and protection; (2) freedom from illness, danger, pain; (3) job security, financial situation; (4) insurance; (5) retirement; (6) future satisfaction of physical needs.

Finally, physiological need was divided as follows: (1) food and water; (2) shelter; (3) sleep/rest; (4) air; (5) exercise, sensory stimulation; (6) proper nutrition/vitamins; (7) freedom from disease and pain.

2.5 Herzberg et al. [13] described an extension of Maslow's theory as applied to a workplace, and thus included workers' motivations. Breaking these down into 'Motivating factors' (satisfiers) and 'Hygene factors (dissatisfiers), Herzberg postulated that factors most likely to motivate or satisfy an individual were: achievement, recognition, work, responsibility, advancement and growth, whilst factors most likely to dissatisfy and individual were: company policy, supervision, working conditions, interpersonal relationships, salary, status, job security and personal life [20]. These ideas focus directly upon what motivates (or demotivates) an individual in the work space.

2.6 Theory X and Theory Y were both proposed by McGregor $[14,15]$ and also based on the Maslow theory, were developed with the direct intent to analyse the features within successful organisations. The two theories represent opposing management styles: theory $\mathrm{X}$ being the traditional view of direction and control, whilst theory $\mathrm{Y}$ focuses on the integration of goals of both the individual and the organisation. Theory $\mathrm{X}$ suggests essentially that most individuals dislike work, and require coercive and directed actuation in order to make them perform. Thus individuals must be closely controlled with the use of threatening action where necessary. Theory Y, by contrast, suggests that where organisational goals are clearly expressed and are inclusive, that individuals will self-direct, and that this will benefit both the individual and organisation [14].

2.7 McClelland's theory of needs $[17,18,19,20]$ states that there are three essential motivational needs, those of power, achievement, and affiliation. Harrell and Stahl [19] suggest that those with pronounced power needs tend to seek leadership positions where they have the ability to influence and direct others, whilst those with achievement needs are attracted to work environments where they have personal responsibility and the potential to advance. Individuals with strong affiliation needs are those who thrive on developing close and trusting relationships. These individuals might experience conflict in leadership roles because such roles will interfere with the friendship motive.

2.8 There have been a number of comparisons of these and other different motivational theories, such as Fisher [16], Pardee [20], Weinberger and McClelland [22], and Dickinson [23], whilst other authors have sought to integrate or combine motivational theory for a specific purpose - examples being Steel and Konig [24], Royle et al [25], Yearta et al [26], Notz [27], Meriam et al [28], Katzell and Thompson [29], Stipek [30]. In order to understand which theory of motivation might be most suitable for this research, it is necessary to briefly compare theories. Pardee [20] compares these theories, and identifies commonalities in that Maslow [12], Herzberg [13], and McClelland [17] all identify self-fulfilment and achievement as being a dominating motivational factor, whilst Maslow's [12] basic needs might be seen to be analogous to many of Herzberg's [13] 'dissatisfiers' - e.g. working conditions, and job security. McGregor's Theory Y, meanwhile, suggests that harmonisation between the individual and organisational objectives can lead to the realisation of the individual's goals through encouraging human creativity [14].

2.9 The focus of this research is the need to understand perception of events, driving decision making in the military context. Kuhl [31] suggests that decision making - the deliberate choice between goals and action alternatives - is related to "simultaneous changes in several competing motivational tendencies that are not necessarily mediated by conscious thought (dynamic change)... and the maintenance and enactment of intentions- that is, action tendencies the organism has committed itself to execute despite the press resulting from many alternative action tendencies (action control)". This suggests a need to understand and compute the effect of competing motives, events and potential outcomes before taking a decision. Larrick [32] links this to the perception of risk, whilst Scarantino [33] highlights the effect that emotion might have upon motivation; this being so, it would clearly affect the ability to make rational decisions. Using these factors, the need can be seen to identify the theory which allows for the greatest range of coverage so that all motivating factors might be taken into account. It can be seen from Pardee's [20] analysis that there are commonalities shared between many of the theories. However, McGregor's Theory X and Y [14, 15] focus heavily on how individuals can be managed within the workplace, and this can be seen not to relate directly to the focus of this research. Similarly, McLelland's Needs Theory $[17,18]$ does not fit directly either, focusing as it does on power, achievement and affiliation. The variables which might affect each of these needs are broad and potentially diverse, and as such extend beyond the bounds of this study. Herzberg et al [13] focus specifically upon the work place, which is out of context for this study, and also concentrate on identifying factors which motivate and demotivate, rather than those which influence perception and decision making. To an extent, this can also be said of Maslow [12], but the motivational scale detailed at section 2.4 is sufficiently broad to allow the authors to deem Maslow as the most suitable theory of motivation for this study. This was chosen because it offered the simplest basis upon which to generate a useful tool for the evaluation of military campaigns. It is also the theory which is most widely known amongst the most likely wargame audience of UK military personnel. This familiarity was thought to will be a driver to provide some confidence to them which is a key element of successful wargames practice. 


\section{METHODOLOGY}

\subsection{Approach}

3.1.1 The approach taken for the application to the RCAT marker tracks was to identify the appropriate theory with the relevant characteristics. As described, on reviewing the background literature in Section II, the baseline Maslow theory was chosen.

3.1.2 The aim was to use the Maslow hierarchy elements and then attempt to map these against a set of effects which might occur in a military campaign in order to generate a numerical change in the marker track levels. However, in order to accomplish this it was necessary to establish a numerical value or weighting representing the relative importance of each level in the Maslow hierarchy. Various authors have used Maslow's hierarchy of needs to provide a basis for the measurement of factors such as wellbeing in significant population groups (Goodman [34], Clarke et al. [35] and Hagerty, [36]). However no single approach or set of weights for priorities has been identified.

3.1.3 Once the Maslow hierarchy could be quantified in some way then the other aspect of the investigation was to identify suitable effects in military campaigns that could be assessed against the appropriate human impact. The principal effects considered in the study were Violence, Atrocity/intimidation, Collateral damage, Occupation, Patrolling/Presence, Threatening Messages, Reassuring Messages, and 'Build Aid Provide' (humanitarian support). The impact or contribution of these on the Maslow elements could then also be quantified to provide the required linkage.

\subsection{Methodology summary}

3.2.1 In summary, Maslow's hierarchy of needs has been applied to a generic situation by examining the levels (Section II) and then by assessing the impact of military and other effects (Section III) on the elements of this hierarchy.

Maslow's hierarchy of needs was consequently developed into a quantified interconnected model which allows an effect (military or campaign effect) to influence a specific element of the hierarchy, resulting in a positive or negative effect on perception. The level on the appropriate marker track is then modified accordingly. This then forms the set of criteria against which the consequences of the effects and actions in the wargame can be assessed.

\subsubsection{The methodology comprised three tasks:}

- Quantification of the perceived importance of elements within Maslow's hierarchy of needs, then separately

- Quantification of the impact of military effects on each of these elements

- Overall combined quantification of the effects and their implementation in the marker track system.

\section{MASLOW HIERARCHY PRIORITISATION AND CONSISTENCY OF WEIGHTINGS}

4.1 This first step was to prioritise the elements in the Maslow hierarchy. This was achieved by producing and examining an initial set to establish the feasibility of the approach. This was completed first by one individual; clearly there was no confidence that this weighting would be generally applicable, so a simple experiment was planned and conducted to gather a range of priorities from a range of different people. This would then be analysed to determine whether there was any consistency and to establish if the approach might work more widely for other applications or projects. This initial experimental phase was explored in workshops at the International Symposium on Operational Research (ISMOR) in 2017. ISMOR is a conference held every year in the UK involving Defence Operational Researchers and analysts from a number of countries. The attendance is usually around 100 people in total. The conference has a small session allowing exposure of ideas and participation in workshops and it was this mechanism that was used This was chosen as it allowed a substantial group of people with varied backgrounds to participate in the generation of a set of weightings and to analyse these findings.

4.2 The workshops collected data in two phases on scoring and weighting and this was done anonymously. In the first phase (phase one) individuals were asked to score the perceived importance of the Maslow hierarchy levels. This was without reference to any scenario; it was simply to capture what they felt were the priorities. They were also asked for comments on their perception of the robustness or the variation of their scores in changing situations. This was intended as a twofold examination, principally to generate an initial set of priorities for the hierarchy of needs for application in a representative situation, but also to gauge individual views on the importance or weighting of Maslow's elements. The first phase was followed by a second phase. In this phase the same group of respondents were asked to assess the impact of the military effects on the Maslow hierarchy elements, that is, they were asked whether such an effect (military effect) would have a positive or negative impact. In effect they scored the impact with a +1 or -1 , or no effect (zero). Again this was used to determine the individual's scores and, more importantly, whether there was any consistency between individuals. The following sections explain and illustrate the data capture and analysis. 


\subsection{Maslow Hierarchy Prioritisation Data Capture}

4.3.1 The data were captured on blank matrices provided to each respondent. The first matrix showed the Maslow hierarchy elements down the leftmost column and a column for entering an importance score. The audience was made familiar with the problem and was then asked to complete the matrix separately. Some twenty people attended the workshop and from these there were fourteen Maslow hierarchy matrices which were completed and others were partially filled against the major Maslow hierarchy headlines. Guidance on a scoring regime was not included, thus allowing individual freedom of choice. The matrices were then rationalised into a standard set of scores by the principal author.

\subsection{Maslow Hierarchy Prioritisation Results and Analysis}

TABLE I

AVERAGE VALUES AND VARIANCES BASED ON 14 RESPONDENTS SCORING THE TOP LEVEL CRITERIA OF MASLOW'S HIERARCHY OF NEEDS.

\begin{tabular}{|l|l|l|l|l|}
\hline Elements & Average & $\begin{array}{l}\text { Standard } \\
\text { Deviation } \\
(\text { SD })\end{array}$ & 1 SD Up & $\begin{array}{l}\text { 1 SD } \\
\text { Down }\end{array}$ \\
\hline Actualisation & 4.11 & 3.44 & 7.55 & 0.67 \\
\hline Esteem & 13.76 & 8.36 & 22.11 & 5.40 \\
\hline $\begin{array}{l}\text { Belonging } \\
\text { and Love }\end{array}$ & 17.23 & 4.65 & 21.88 & 12.58 \\
\hline Safety & 28.61 & 4.88 & 33.48 & 23.73 \\
\hline Physiological & 36.57 & 9.75 & 46.33 & 26.82 \\
\hline
\end{tabular}

4.4.1 Table I summarises the results captured at the ISMOR conference. The first thing to note is that the average scores were consistent with the order Maslow's priorities, i.e. physiological needs were considered the highest priority followed by safety, belonging, esteem and finally actualisation. The variances in the scores represented by the standard deviations (SD), with upper and lower bounds based on one SD for each characteristic, are shown in Fig. 2.

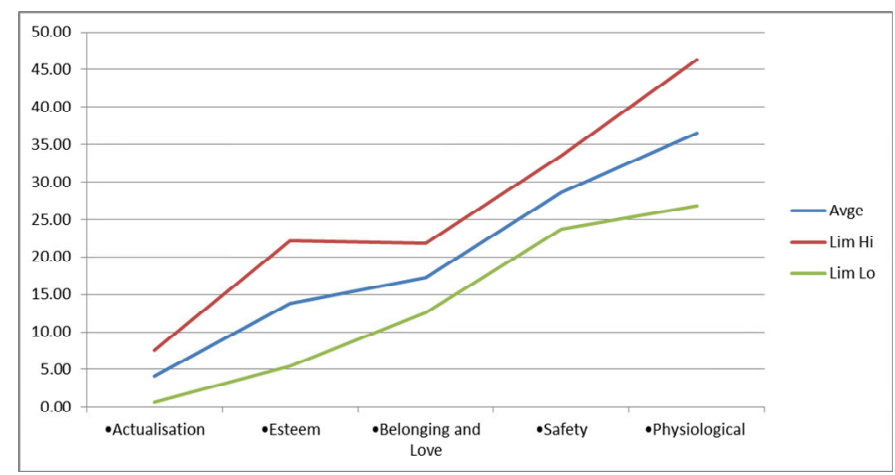

Fig. 2. Average scores for the five elements of Maslow's hierarchy of needs with upper and lower bounds of one standard deviation, based on the scores of 14 respondents at the 2017 ISMOR conference.

4.4.2 Starting with the lowest priority (Actualisation), there was a limited potential for overlap with Esteem. The upper bound for Actualisation (7.6) was well below the average score for Esteem (13.8) and only marginally above the lower bound of Esteem (5.4). This suggested that the order is correct and that the lowest weighting in a wargaming analysis should be applied to Actualisation. Ordering the next two levels was more challenging because the upper bound for Esteem (22.1) was well above the average score for Belonging and Love (17.2) and of course its lower bound (12.6). These elements therefore need further evaluation to discern any differences between them, and in any wargaming analysis it is proposed that they should be equally weighted.

4.4.3 Safety was the next criterion and this was clearly separated from Belonging and Love with no overlap at all between the lower bound of the former and upper bound of the latter. The Safety criterion should therefore be weighted higher than the previous two. Finally, Physiological Needs showed the highest weighting, with the lower bound (26.8) just below the average for safety (28.6) and well below the upper bound for Safety (33.5). However, the latter was far below the average score for Physiological Needs (36.6) indicating there should be a difference in weighting between Physiological and Safety needs within a wargame scenario. 


\subsection{Maslow Hierarchy Prioritisation and Consistency of Weightings}

4.5.1 Based on the analysis of average scores and the corresponding variances, the initial weighting applied to the wargame effects matrix is shown in Table II. These weightings are simply based on the scores in the tables above converted into a consistently scaled series.

\begin{tabular}{|l|r|}
\hline & Weight \\
\hline Actualisation & 0.5 \\
\hline Esteem & 1.5 \\
\hline Belonging and Love & 1.5 \\
\hline Safety & 3 \\
\hline Physiological & 3.5 \\
\hline
\end{tabular}

TABLE II INITIAL WEIGHTING FOR WARGAME EFFECTS MATRIX

\subsection{Quantifying Wargame and Combat Effects Against Maslow's Hierarchy of Needs}

4.6.1 The final step in the analysis was to generate data to measure the impact of each RCAT wargame effect on each of Maslow's elements, in order to drive the calculation for the overall quantitative effect on a RCAT wargame marker track. Note that no wargames were run for this phase, rather the effects that can occur in an RCAT wargame were used as inputs. Prior to the experiment, a matrix approach was developed and again it uses a set of cross-impact scores. An initial illustrative matrix was generated by the authors and is shown in Table III. This example matrix lists Maslow's elements and sub-elements in the leftmost columns followed by a simple and then combined weighting value. In this illustrative matrix which was produced prior to the Workshop, we have not incorporated the weights from Table II. The wargame effects are listed across the top of the matrix. The matrix is completed by entering a set of scores in the cells to indicate the impact of each wargame effect on Maslow's elements. For this element the scores were defined as follows; 1 (Green) indicating a positive effect and -1 (Red) indicating a negative effect. The weighted scores are summed in the bottom row, yielding figures ranging from -6 to 4.7. This indicates the overall impact of a wargame effect on the entire hierarchy of needs.

\begin{tabular}{|c|c|c|c|c|c|c|c|c|c|c|c|c|c|}
\hline \multirow[t]{2}{*}{ Maslow List } & & \multicolumn{2}{|c|}{ 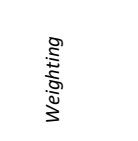 } & \multirow[t]{2}{*}{ 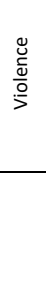 } & \multirow[t]{2}{*}{ 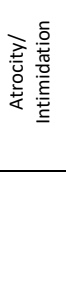 } & \multirow[t]{2}{*}{ 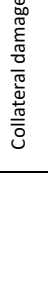 } & \multicolumn{2}{|c|}{$\begin{array}{l}\overline{0} \\
+\overline{0} \\
\bar{\Xi} \\
\bar{\Xi} \\
0\end{array}$} & \multicolumn{2}{|c|}{ 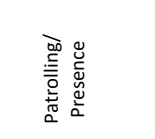 } & \multirow[t]{2}{*}{ 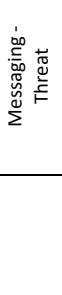 } & \multirow[t]{2}{*}{ 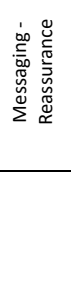 } & \multirow[t]{2}{*}{$\frac{a}{\infty}$} \\
\hline & & & & & & & $\begin{array}{l}\text { to } \\
\text { 을 } \\
\text { ज. }\end{array}$ & $\begin{array}{l}\text { ڤ̆ } \\
\text { о응 }\end{array}$ & $\begin{array}{l}\frac{5}{0} \\
\frac{0}{2} \\
\bar{s}^{2}\end{array}$ & 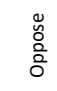 & & & \\
\hline \multicolumn{14}{|l|}{-Actualisation } \\
\hline \multicolumn{14}{|l|}{ •Esteem } \\
\hline \multirow[t]{4}{*}{-Self Esteem } & $\begin{array}{l}\text { Achievement, } \\
\text { competence }\end{array}$ & 1 & 0.1429 & & & & 1 & -1 & & & & & \\
\hline & Confidence & 1 & 0.1429 & & -1 & & 1 & -1 & 1 & -1 & -1 & 1 & \\
\hline & Independence & 1 & 0.1429 & & & & 1 & -1 & 1 & -1 & & & \\
\hline & $\begin{array}{l}\text { Usefulness, self } \\
\text { worth }\end{array}$ & 1 & 0.1429 & & -1 & & 1 & -1 & 1 & -1 & -1 & & \\
\hline \multirow[t]{3}{*}{-Esteem from Others } & Reputation, prestige & 1 & 0.1429 & & & & & & & & & & \\
\hline & $\begin{array}{l}\text { Attention, } \\
\text { appreciation }\end{array}$ & 1 & 0.1429 & & & & 1 & -1 & 1 & -1 & & & \\
\hline & $\begin{array}{l}\text { Recognition, } \\
\text { importance }\end{array}$ & 1 & 0.1429 & & & & & & & & & & \\
\hline \multicolumn{14}{|l|}{ •Belonging and Love } \\
\hline & $\begin{array}{l}\text { To be kind, express } \\
\text { affection }\end{array}$ & 1 & 0.3333 & & & & & & & & & & \\
\hline & $\begin{array}{l}\text { To be responsible, } \\
\text { share }\end{array}$ & 1 & 0.3333 & & & & & & & & & & \\
\hline & $\begin{array}{l}\text { To give love be } \\
\text { intimate }\end{array}$ & 1 & 0.3333 & & & & & & & & & & \\
\hline & $\begin{array}{l}\text { To be loved, receive } \\
\text { affection }\end{array}$ & 1 & 0.3333 & & & & & & & & & & \\
\hline & $\begin{array}{l}\text { To belong, be } \\
\text { accepted }\end{array}$ & 1 & 0.3333 & & & & & & & & & & \\
\hline & $\begin{array}{l}\text { To have friends and } \\
\text { family }\end{array}$ & 1 & 0.3333 & & & & & & & & & & \\
\hline
\end{tabular}




\begin{tabular}{|c|c|c|c|c|c|c|c|c|c|c|c|c|c|}
\hline - Safety & & & & & & & & & & & & & \\
\hline & $\begin{array}{l}\text { Freedom from } \\
\text { danger }\end{array}$ & 1 & 0.4286 & -1 & -1 & -1 & 1 & -1 & 1 & -1 & -1 & 1 & 1 \\
\hline & Orderly world & 1 & 0.4286 & -1 & -1 & -1 & 1 & 1 & 1 & -1 & -1 & 1 & \\
\hline & Predictable, stable & 1 & 0.4286 & -1 & -1 & & 1 & -1 & 1 & -1 & -1 & 1 & \\
\hline & Job tenure & 1 & 0.4286 & & & -1 & 1 & -1 & 1 & -1 & -1 & 1 & \\
\hline & Financial & 1 & 0.4286 & & & -1 & 1 & -1 & 1 & -1 & -1 & 1 & \\
\hline & Insurance & 1 & 0.4286 & & & & & & & & & & \\
\hline & Retirement & 1 & 0.4286 & & & & & & & & & & \\
\hline \multicolumn{14}{|l|}{-Physiological } \\
\hline & Food and Water & 1 & 1.4286 & -1 & & -1 & & & & & & & 1 \\
\hline & Shelter & 1 & 1.4286 & -1 & & -1 & & & & & & & 1 \\
\hline & Sleep/Rest & 1 & 1.4286 & -1 & & -1 & 1 & -1 & 1 & -1 & & & 1 \\
\hline & Air & 1 & 1.4286 & & & & & & & & & & \\
\hline & $\begin{array}{l}\text { Exercise, sensory } \\
\text { stimulation }\end{array}$ & 1 & 1.4286 & & & & & & & & & & \\
\hline & Sex & 1 & 1.4286 & & & & & & & & & & \\
\hline & $\begin{array}{c}\text { Proper } \\
\text { nutrition/vitamins } \\
\end{array}$ & 1 & 1.4286 & & & & & & & & & & \\
\hline & Weighted Sum & & & -5.57 & -1.57 & -6 & $\begin{array}{c}4.2 \\
8\end{array}$ & -3.4 & 4.11 & -4.14 & -2.42 & 2.28 & 4.7 \\
\hline
\end{tabular}

TABLE III. DRAFT SCORING MATRIX TO QUANTIFY WARGAME EFFECTS AGAINST MASLOW'S HIERARCHY OF NEEDS, SHOWING ARBITRARY WEIGHTINGS BEFORE EVALUATION.

4.6.2 However note that this is an example to prove the format and as such this set was simply used as an initial 'seeding' to establish that the method was feasible. The ISMOR workshop again was used to capture new data. The aim was to gather new scores from Workshop participants then analyse these to assess any variability between respondents completing these new scores. This would therefore provide some information on the utility of the method and, if there were to be agreement, these could be used to populate a combined matrix. The respondents at the ISMOR workshop were asked to complete a blank version of the Table III matrix with scores for the impact of a military effect of the types that would occur in the RCAT wargame on a local population in a conflict area. The respondents were asked to use a standard 1 and -1 to indicate positive and negative effects, respectively. Whereas 14 respondents had offered weightings for Maslow's hierarchy of needs, only nine completed the matrix of these cross-impact scores. Several respondents also provided multiple scores with notes to explain their differing interpretations (mainly under the atrocity/intimidation category) and a small number of cells featured amendments or corrections, which were handled on a case-by case basis.

4.6.3 Initially the analysis considered how many cells were filled among the 330 available, which ranged from a minimum of 18 to a maximum of 154 . The consistency of the answers was also evaluated to determine their suitability for the RCAT wargames. During the review, any cells that were not filled by at least four respondents were discarded because this indicated that less than half of the group had entered a score. Following this data streamlining procedure, 63 cells were found to satisfy the inclusion criteria and 50 of these shown remarkably consistent values, with all respondents agreeing on a score of 1 or -1 . The cells with the most inconsistent scores are listed below:

- Impact of occupation, where the population support the occupiers, on independence (under self-esteem).

- Impact of violence on be responsible/share (therefore this value is set in the final Matrix at the average value of -0.5)

- Impact of patrolling/presence, where the population support the occupiers, on security and independence.

- Impact of reassuring messaging on independence (therefore this value is set in the final Matrix at the average of 0.714).

- Impact of occupation and patrolling/presence on the initial three sub-elements of safety, namely: freedom from danger, orderly world, and predictable/stable.

4.6.4 This indicates the greatest degree of inconsistency in the effects of occupation and patrolling/presence in the RCAT wargame. Due to this apparent inconsistency (or lack of consistency) in the responses, these elements (occupation and patrolling) were excluded from the final direct effect calculation matrix. It was remarkable to note, however, the almost complete consistency in the judgement of the impact of the other effects so these should be included with some confidence in the final direct effect calculation matrix. 


\section{FinAL COMBINATION MATRIX}

5.1 Based on the evaluation process described above, a final matrix was constructed to combine the weightings for the importance of the elements of the Maslow hierarchy of needs and the individual impacts of the RCAT effects on these elements (Table IV). As in the earlier iterations of the matrix, the Maslow elements and sub-elements are listed in the two leftmost columns, followed by the weightings identified and recommended in Section 4 (the Weights for the Categories are found in Table II and noted in the Table Below). The scores in the main body of the matrix are the impact scores generated in Section 4. Again, as shown above, the scores at the foot of the columns (penultimate row, shown as Raw Weighted Sum) are the scores in the matrix multiplied by the weightings and then summed.

\begin{tabular}{|c|c|c|c|c|c|c|c|c|c|c|c|c|c|}
\hline & & & & \multicolumn{10}{|c|}{ Campaign Event/Effect } \\
\hline Maslow List & & \multicolumn{2}{|c|}{ 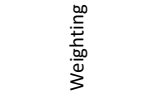 } & 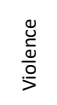 & 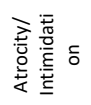 & 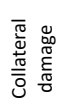 & \multicolumn{2}{|c|}{ 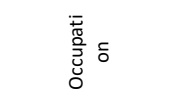 } & \multicolumn{2}{|c|}{ 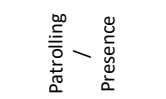 } & \multirow[t]{2}{*}{ 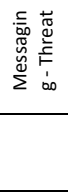 } & \multirow[t]{2}{*}{ 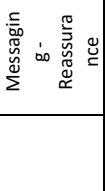 } & \multirow[t]{2}{*}{ 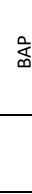 } \\
\hline -Actualisation & & $\begin{array}{c}0.5 \\
\text { (Table } \\
\text { II) }\end{array}$ & & & & & Support & Oppose & Support & Oppose & & & \\
\hline \multicolumn{14}{|l|}{ •Esteem } \\
\hline \multirow[t]{4}{*}{ Self Esteem } & $\begin{array}{l}\text { Achievement, } \\
\text { competence }\end{array}$ & 1 & 0.2143 & 0 & 0 & 0 & & & & & 0 & 0 & 0 \\
\hline & Confidence & 1 & 0.2143 & -1 & -1 & 0 & & & & & -1 & 1 & 0 \\
\hline & Independence & 1 & 0.2143 & 0 & -1 & 0 & & & & & -1 & 0.714 & 0 \\
\hline & $\begin{array}{l}\text { Usefulness, self } \\
\text { worth }\end{array}$ & 1 & 0.2143 & 0 & 0 & 0 & & & & & 0 & 1 & 0 \\
\hline \multirow{4}{*}{$\begin{array}{l}\text { Esteem from } \\
\text { Others }\end{array}$} & $\begin{array}{c}\text { Reputation, } \\
\text { prestige }\end{array}$ & 1 & 0.2143 & 0 & 0 & 0 & & & & & 0 & 0 & 0 \\
\hline & $\begin{array}{l}\text { Attention, } \\
\text { appreciation }\end{array}$ & 1 & 0.2143 & 0 & 0 & 0 & & & & & 0 & 0 & 0 \\
\hline & $\begin{array}{l}\text { Recognition, } \\
\text { importance }\end{array}$ & 1 & 0.2143 & 0 & 0 & 0 & & & & & 0 & 0 & 0 \\
\hline & Sum of Weights & $\begin{array}{l}\text { (Table } \\
\text { III) }\end{array}$ & 1.5 & & & & & & & & & & \\
\hline \multicolumn{14}{|c|}{-Belonging and Love } \\
\hline & $\begin{array}{c}\text { To be kind, } \\
\text { express } \\
\text { affection }\end{array}$ & 1 & 0.25 & 0 & 0 & 0 & & & & & 0 & 0 & 0 \\
\hline & $\begin{array}{c}\text { To be } \\
\text { responsible, } \\
\text { share }\end{array}$ & 1 & 0.25 & -0.5 & 0 & 0 & & & & & -1 & 1 & 0 \\
\hline & $\begin{array}{l}\text { To give love be } \\
\text { intimate }\end{array}$ & 1 & 0.25 & -1 & 0 & 0 & & & & & 0 & 0 & 0 \\
\hline & $\begin{array}{l}\text { To be loved, } \\
\text { receive } \\
\text { affection }\end{array}$ & 1 & 0.25 & -1 & 0 & 0 & & & & & 0 & 0 & 0 \\
\hline & $\begin{array}{l}\text { To belong, be } \\
\text { accepted }\end{array}$ & 1 & 0.25 & 0 & 0 & 0 & & & & & 0 & 0 & 0 \\
\hline & $\begin{array}{l}\text { To have friends } \\
\text { and family }\end{array}$ & 1 & 0.25 & -1 & -1 & -1 & & & & & 0 & 0 & 0 \\
\hline & Sum of Weights & $\begin{array}{c}\begin{array}{c}\text { (Table } \\
\text { III) }\end{array} \\
\text { (1) }\end{array}$ & 1.5 & & & & & & & & & & \\
\hline \multicolumn{14}{|l|}{-Safety } \\
\hline & $\begin{array}{l}\begin{array}{l}\text { Freedom from } \\
\text { danger }\end{array} \\
\end{array}$ & 1 & 0.4286 & -1 & -1 & -1 & & & & & -1 & 1 & 0 \\
\hline & Orderly world & 1 & 0.4286 & -1 & -1 & -1 & & & & & -1 & 1 & 0 \\
\hline & $\begin{array}{l}\text { Predictable, } \\
\text { stable }\end{array}$ & 1 & 0.4286 & -1 & -1 & -1 & & & & & -1 & 1 & 0 \\
\hline & Job tenure & 1 & 0.4286 & -1 & 0 & -1 & & & & & -1 & 1 & 0 \\
\hline & Financial & 1 & 0.4286 & -1 & -1 & -1 & & & & & 0 & 1 & 0 \\
\hline & Insurance & 1 & 0.4286 & -1 & -1 & -1 & & & & & 0 & 0 & 0 \\
\hline & Retirement & 1 & 0.4286 & 0 & 0 & 0 & & & & & 0 & 0 & 0 \\
\hline & Sum of Weights & $\begin{array}{c}\text { (Table } \\
\text { II) }\end{array}$ & 3.0 & & & & & & & & & & \\
\hline \multicolumn{14}{|l|}{-Physiological } \\
\hline & $\begin{array}{c}\begin{array}{c}\text { Food and } \\
\text { Water }\end{array} \\
\end{array}$ & 1 & 0.7 & -1 & 0 & -1 & & & & & 0 & 0 & 1 \\
\hline & Shelter & 1 & 0.7 & -1 & 0 & -1 & & & & & 0 & 0 & 0 \\
\hline
\end{tabular}




\begin{tabular}{|c|c|c|c|c|c|c|c|c|c|c|c|c|}
\hline Sleep/Rest & 1 & 0.7 & -1 & -1 & -1 & & & & & -1 & 1 & 0 \\
\hline Air & 1 & 0.7 & 0 & 0 & 0 & & & & & 0 & 0 & 0 \\
\hline $\begin{array}{c}\text { Exercise, } \\
\text { sensory } \\
\text { stimulation }\end{array}$ & 1 & 0.7 & -1 & 0 & 0 & & & & & 0 & 0 & 0 \\
\hline Sum of Weights & $\begin{array}{c}\text { (Table } \\
\text { II) }\end{array}$ & 3.5 & & & & & & & & & & \\
\hline $\begin{array}{l}\text { Raw } \\
\text { Weighted } \\
\text { Sum }\end{array}$ & & & $\begin{array}{c}- \\
6.460 \\
71429\end{array}$ & $\begin{array}{c}- \\
3.521 \\
42857\end{array}$ & -4.92143 & 0 & 0 & 0 & 0 & $\begin{array}{c}- \\
3.092 \\
857\end{array}$ & $\begin{array}{c}3.674 \\
49\end{array}$ & 0.7 \\
\hline \multicolumn{3}{|c|}{$\begin{array}{l}\text { Normalised and modified } \\
\text { for RCAT changes }\end{array}$} & -2 & -1 & -2 & 0 & 0 & 0 & 0 & -1 & 1 & 0 \\
\hline
\end{tabular}

TABLE IV. FINAL COMPLETE SCORING MATRIX TO QUANTIFY WARGAME EFFECTS AGAINST MASLOW'S HIERARCHY OF NEEDS,

\subsection{Implementation of RCAT Wargame Marker Track Variation}

5.2.1 Clearly the sums in the final combination matrix (Table IV) are large numbers and if used directly in the RCAT marker track system they would need to be calibrated to avoid large swings for each event. The raw numbers were therefore normalised to ensure that the marker track levels can move only by a maximum of two increments per effect (which is still a significant change). The final normalised impact listed in the last row of Table IV are repeated and summarised below in Table V.

\begin{tabular}{|c|c|}
\hline RCAT Effect & $\begin{array}{c}\text { Marker Track } \\
\text { Impact }\end{array}$ \\
\hline Violence & -2 \\
\hline $\begin{array}{c}\text { Atrocity/ } \\
\text { Intimidation }\end{array}$ & -1 \\
\hline $\begin{array}{c}\text { Collateral } \\
\text { damage }\end{array}$ & -2 \\
\hline \multirow{2}{*}{\begin{tabular}{c} 
Occupation \\
\cline { 2 - 2 }
\end{tabular}} & 0 \\
\hline $\begin{array}{c}\text { Patrolling/ } \\
\text { Presence }\end{array}$ & 0 \\
\hline $\begin{array}{c}\text { Messaging - } \\
\text { Threat }\end{array}$ & -1 \\
\hline $\begin{array}{c}\text { Messaging - } \\
\text { Reassurance }\end{array}$ & 1 \\
\hline BAP & 0 \\
\hline TABLE V
\end{tabular}

MARKER TRACK INCREMENTS REFLECTING VARIOUS RCAT EFFECTS.

5.2.2 In order to use this data in an RCAT wargame the game control staff would note the occurrence of one or more of these effects in a Turn or in a timestep. These would be used to drive changes during the turn on the relevant marker tracks - ie those that represent the relevant affected population groups. For example, if there were an event where some kinetic operation caused collateral damage (perhaps an artillery strike) in a town area then the local population marker tracks for that town would reduce the support level by 2 for the faction that caused the damage. This would be done immediately after the event had occurred. The game control staff would collect and implement all changes to all tracks throughout the turn as it progressed. At the end of the turn the usual RCAT approach is to gather a subgroup to review these 'automated' changes and discuss and moderate them.

\section{CONCLUSION}

6.1 In this paper, we have presented a method to quantify the impact of certain effects within a wargame on the perception of the conflict by a local population within the conflict area subject to these effects. We first conducted an experiment using subjects to generate weighting values to determine the importance of the elements in Maslow's hierarchy of needs. This was then followed by a further step (in the linked experiment) to independently identify the impact of a set of wargame effects which can occur in the RCAT wargame on the elements within the Maslow hierarchy. This has produced an auditable set of quantified impacts for use when the RCAT wargame is deployed. The outcomes provide some confidence that the approach could be used in a real application since the data can be captured from a group of people offering scores and can be combined into an easy to examine table.

6.2 This method is an improvement over the previous RCAT manual wargame system, which was dependent on the purely subjective judgement of a small subset of those participating in the wargame. Our improved approach continues to use the marker tracks as a means to portray support or dissent, but has a more auditable and objective method for linking events to 
changes and levels on the tracks. It is accepted that this is still using subjectively derived data as was the previous approach but this has the advantage that the data can be derived prior to the game and provide a more consistent response. It is also evident that as it stands the system is a linear system that in itself does not examine prior events.

6.3 Although the results are based on small sample sizes and cannot be regarded as completely objective, the exclusion of variable weightings allowed us to base the evaluation on a largely consistent dataset. Our new method therefore provides a transparent solution which can easily be understood by military or security analysts, therefore facilitating development and change. The method is also still consistent with the approach used in the RCAT wargame where the results are proposed and then discussed and accepted. This element of review after the automatic generation of 'proposed' results would allow incorporation of prior events to be taken into account to moderate the 'raw' generated change.

6.4. The capture of data on the Maslow Hierarchy prioritisation and the impact of the effects in the wargame or simulation on the Hierarchy Elements and consequently on the levels of support on a Marker Track would be repeatable using representative people.

6.5 The method is easy to re-implement as required to apply it to a fresh scenario or setting or into a different wargaming tool. It does not rely on using RCAT. The approach is also clearly applicable to developing simple algorithms to be used to generate and update Marker Tracks within a computer based wargame simulation.

\section{REFERENCES}

1. Kipp, Jacob et al, "The Human Terrain System: A CORDS for the 21st Century ". Military Review September-October 2006: $8-15$.

2. Rubel Robert, US Naval War College Digital Commons, “The Epistemology of Wargaming”,US Naval War College Review Vol 59 No 22006

3. Dunnigan, J, "Wargames, pre-emption and a lot of other curious behaviour", Proceedings of the 2003 Winter Simulation Conference 7-10 Dec. 2003, IEEE

:

4. Taylor B, Land A, "Development of a novel family of military campaign simulation models" ,Journal of the Operational Research Society 55(4):333-339 - April 2004

5. Smith, J, Longley-Brown G, Velicogna A, Ringrose T, 'Rapid Campaign Analysis Toolset Rules v5.0’, Cranfield University, Shrivenham, UK, CU/CDE25765/RL/4, 2016

6. Appleget, G, "Modeling Human Terrain”, 2017, http://www.professionalwargaming.co.uk/ModelingHumanTerrain.pdf Accessed

7. N. Sandell, R. Savell, D. Twardowski, G. Cybenko

"HBML: A Representation Language for Quantitative Behavioral Modeling in the Human Terrain"

Thayer School of Engineering

Dartmouth College, December 13, 2008 Available:

https://www.dartmouth.edu/ humanterrain/papers/sbp09_savell_cybenko_12-13-082.pdf

8. Silverman Barry G, "Human Terrain Data - What Should We Do With It?", University of Pennsylvania

Scholarly Commons, Departmental Papers (ESE) Department of Electrical \& Systems Engineering,

University of Pennsylvania, 12-1-2007

9. Cambridge Online Dictionary, https://dictionary.cambridge.org/dictionary/english/motivation (accessed March 10th 2020)

10. Yorks, L. “A radical approach to job enrichment”, Amacom: New York, 1976

11. Dessler, G. “Organization theory, Integrating Structure, and Behavior”, $2^{\text {nd }}$ Ed., Prentice-Hall: New Jersey, 1986

12. Maslow, A.H. "A theory of human motivation". Psychological Review. 50 (4): 370-96, 1943

13. Herzberg, Frederick; Mausner, Bernard; Snyderman, Barbara B. "The Motivation to Work (2nd ed.)”. New York: John Wiley. 1959. 
14. McGregor, Douglas. "Theory X and theory Y." Organization theory 358 (1960): 374.

15. McGregor, D, 'The human side of enterprise', New York : McGraw-Hill, 1960.

16. Fisher, Elizabeth A. "Motivation and leadership in social work management: A review of theories and related studies." Administration in social work 33, no. 4 (2009): 347-367.

17. McClelland, David C. "How motives, skills, and values determine what people do." American psychologist 40, no. 7 (1985): 812.

18. McClelland, David C. Human motivation. CUP Archive, 1987.

19. Harrell, Adrian M., and Michael J. Stahl. "McClelland's trichotomy of needs theory and the job satisfaction and work performance of CPA firm professionals." Accounting, Organizations and Society 9, no. 3-4 (1984): 241-252.

20. Pardee, Ronald L. "Motivation Theories of Maslow, Herzberg, McGregor \& McClelland. A Literature Review of Selected Theories Dealing with Job Satisfaction and Motivation." (1990).

21. Stein, HT, "Maslow's Hierarchy of Needs and The Stages of Classical Adlerian Psychotherapy", Alfred Adler Institutes of San Francisco and Northwestern Washington 2005, Available: http://www.adlerian.us/needs2.htm

22. Weinberger, Joel, and McClelland, D. C. "Cognitive versus traditional motivational models: irreconcilable or complementary?." (1990).

23. Dickinson, Leslie. "Autonomy and motivation a literature review." System 23, no. 2 (1995): 165-174.

24. Steel, Piers, and Cornelius J. König. "Integrating theories of motivation." Academy of management review 31, no. 4 (2006): 889-913.

25. Royle, M. Todd, and Angela T. Hall. "The relationship between McClelland's theory of needs, feeling individually accountable, and informal accountability for others." International Journal of Management and Marketing Research 5, no. 1 (2012): 21-42.

26. Yearta, Shawn K., Sally Maitlis, and Rob B. Briner. "An exploratory study of goal setting in theory and practice: A motivational technique that works?." Journal of Occupational and Organizational Psychology 68, no. 3 (1995): 237-252.

27. Notz, William W. "Work motivation and the negative effects of extrinsic rewards: A review with implications for theory and practice." American Psychologist 30, no. 9 (1975): 884.

28. Merriam, Sharan B., and Laura L. Bierema. Adult learning: Linking theory and practice. John Wiley \& Sons, 2013.

29. Katzell, Raymond A., and Donna E. Thompson. "Work motivation: Theory and practice." American psychologist 45, no. 2 (1990): 144.

30. Stipek, Deborah J. "Motivation to learn: From theory to practice." (1993).

31. Kuhl, Julius. "Motivation and information processing: A new look at decision making, dynamic change, and action control." (1986).

32. Larrick, Richard P. "Motivational factors in decision theories: The role of self-protection." Psychological Bulletin 113, no. 3 (1993): 440.

33. Scarantino, Andrea. "The motivational theory of emotions." (2014).

34. Goodman, RA "On The Operationality Of The Maslow Need Hierarchy", British Journal of Industrial Relations Blackwell Publishing Ltd / London School of Economics, Volume 6, Issue 1, pages 51-57, March 1968

35. Clarke M, Sardar M.N., Paecha S, "Measuring Australia's well-being using hierarchical needs", The Journal of SocioEconomics, Volume 35, Issue 6, Pages 933-945, December 2006 
36. Hagerty, M.R., 'Testing Maslow's hierarchy of needs: National Quality-of-Life across time”, Social Indicators Research, Volume 46, Issue 3, 1999, Pages 249-271 